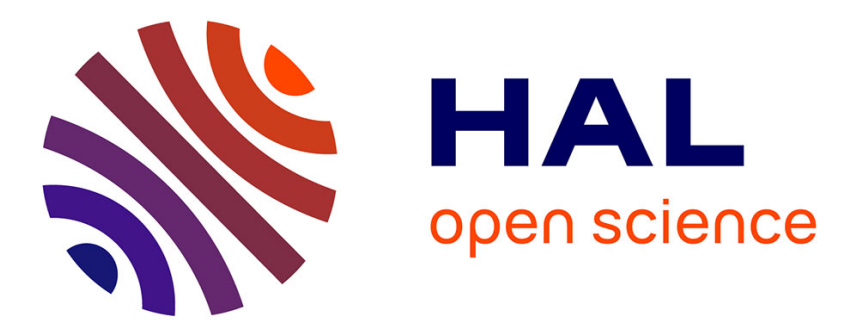

\title{
A new case of reciprocal translocation in a young bull: $\operatorname{rcp}(11 ; 21)(\mathrm{q} 28 ; \mathrm{q} 12)$
}

L Molteni, A Perucatti, A Iannuzzi, G.P. Di Meo, L. de Lorenzi, A. de Giovanni, D Incarnato, G. Succi, Edmond E. Cribiu, Andre A. Eggen, et al.

\section{- To cite this version:}

L Molteni, A Perucatti, A Iannuzzi, G.P. Di Meo, L. de Lorenzi, et al.. A new case of reciprocal translocation in a young bull: rcp (11;21)(q28;q12). Cytogenetic and Genome Research, 2007, 116, pp.80-84. hal-02656177

\section{HAL Id: hal-02656177 https://hal.inrae.fr/hal-02656177}

Submitted on 29 May 2020

HAL is a multi-disciplinary open access archive for the deposit and dissemination of scientific research documents, whether they are published or not. The documents may come from teaching and research institutions in France or abroad, or from public or private research centers.
L'archive ouverte pluridisciplinaire HAL, est destinée au dépôt et à la diffusion de documents scientifiques de niveau recherche, publiés ou non, émanant des établissements d'enseignement et de recherche français ou étrangers, des laboratoires publics ou privés. 


\title{
A new case of reciprocal translocation in a young bull: $\operatorname{rcp}(11 ; 21)(q 28 ; q 12)$
}

\author{
L. Molteni ${ }^{a} \quad$ A. Perucatti ${ }^{b} \quad$ A. Iannuzzic $^{c} \quad$ G.P. Di Meo ${ }^{b} \quad$ L. De Lorenzi ${ }^{a}$

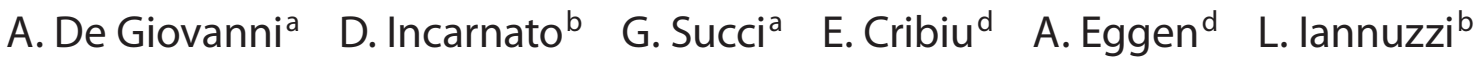 \\ a Institute of Animal Production, Agricultural Faculty of Science, Milan; ${ }^{b}$ National Research Council (CNR), \\ ISPAAM, Laboratory of Animal Cytogenetics and Gene Mapping; ${ }^{\mathrm{c} M S c}$ student of Physiopathology and \\ Reproduction of Domestic Animals, Veterinary Medicine Faculty, University of Naples 'Federico II', Naples (Italy) \\ ${ }^{\mathrm{d}}$ Laboratory of Biochemical Genetics and Cytogenetics, Department of Animal Genetics, INRA, \\ Jouy-en-Josas (France)
}

Manuscript received 2 May 2006; accepted in revised form for publication by M. Schmid, 8 September 2006.

\begin{abstract}
Routine cytogenetic investigations of the Chianina cattle (BTA) breed revealed the presence of longer and smaller chromosomes than the largest (BTA1) and smallest (BTA29) chromosomes in the cells of a young, normal-looking bull used for reproduction. Application of both RBAbanding and Ag-NOR techniques, as well as the use of the FISH technique and specific molecular markers of both BTA11 (IL1B, ASS and LGB) and BTA21 (SERPINA and D21S45) established that these two abnormal chromosomes were the product of a reciprocal translocation between BTA11 and BTA21. Both der(11) and der(21) were C-band positive and the chromosome regions affected were $\operatorname{rcp}(11$;
\end{abstract}

21)(q28;q12). The young bull had a normal body conformation, including external genitalia, normal levels of testosterone (as in the control) and non-detectable levels of both 17 beta-estradiol and progesterone (as in the control). The animal never showed libido in the presence of both males and females in oestrus. After slaughter at 18 months, histological evaluation revealed normal organized testes, seminiferous tubules and epididymis but with poor proliferative germ cells consisting mainly of spermatogonia, middle pachytene spermatocytes and early spermatids with late spermatids and spermatozoa being very rare.

Copyright $\odot 2007$ S. Karger AG, Basel
Numerical autosome aberrations are rare in domestic animals since the carriers show abnormal body conformation (Gustavsson, 1980; Iannuzzi et al., 2001a) and are easily eliminated during the normal breeding program. By contrast, structural chromosome abnormalities of cattle, especially balanced ones, are much more important due to their high frequency (i.e. centric fusions $=\mathrm{cf}$ or rob), normal body conformation of carriers and deleterious effects on fertility. While rob have been widely found in several breeds,

Request reprints from L. Iannuzzi

National Research Council (CNR), ISPAAM

Laboratory of Animal Cytogenetics and Gene Mapping

Via Argine 1085, 80147 Naples (Italy)

telephone: +39081596 4977; fax: +390815965291

e-mail: Leopoldo.Iannuzzi@ispaam.cnr.it especially in meat breeds (Popescu and Pech, 1991; Long, 1995), reciprocal translocations (rcp) appear to be rare in this species. This is probably due to the nature of the autosomes (all acrocentric). Hence, while rob can be easily detected by using normal chromosome staining, rcp are difficult to reveal, especially using conventional chromosome staining or poor banding techniques. Generally, only when abnormal chromosomes (longer or smaller than the largest and smallest chromosomes) are found, subsequent and more detailed cytogenetic analyses may reveal the presence of rcp. Both rob and rcp cause reduced fertility in their carriers since unbalanced gametes (and embryos) are produced which die during early embryonic life. The cow returns to oestrus but with a delay. This increases the time between two following births and reduces the fertility score in the carriers (Gustavsson, 1969, 1980; Dyrendhal and Gustavsson, 1979; Rangel-Figueiredo and Iannuzzi, 1993; Molteni et al., 1994). 

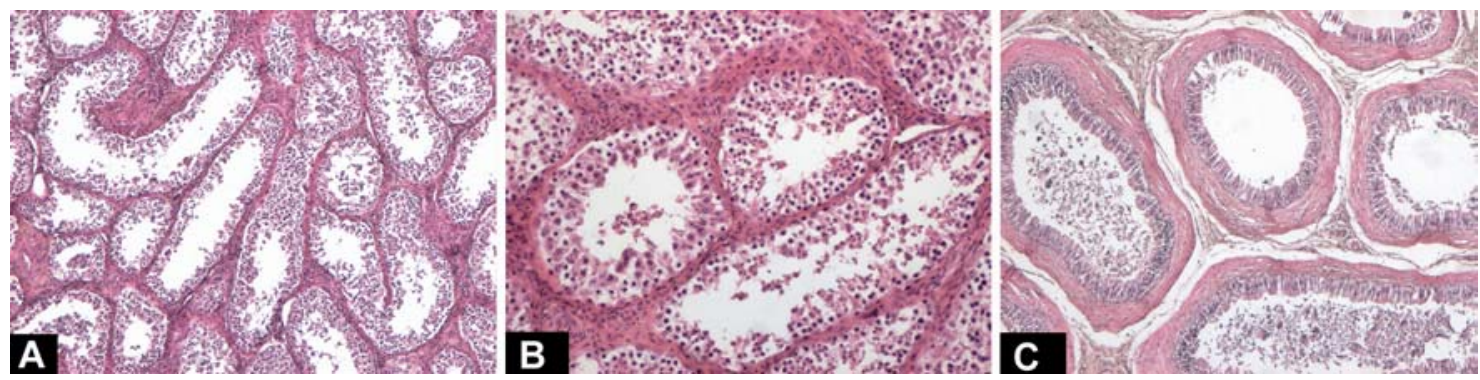

Fig. 1. (A) Histological sections of the testis organized in tubular structures mostly without mature spermatids and spermatozoa. (B) Details of seminiferous tubules almost all without mature spermatids and spermatozoa. (C) Transverse section of the epididymis duct where only desquamate epithelial cells are present with few spermatozoa.

Only a few cases of cattle carrying rcp have been reported until now and they involved only autosomes (de Schepper et al., 1982; Mayr et al., 1983; Kovacs et al., 1992; Ansari et al., 1993; Villagomez et al., 1993; Ducos et al., 2000; Iannuzzi et al., 2001b) or both autosomes and gonosomes (Iannuzzi et al., 2001c). The FISH technique and the availability of both human painting probes and specific molecular markers represent a very useful tool for appreciably increasing the possibility of also detecting rcp and, more important, identify with certainty both chromosomes and chromosome regions involved in these abnormalities (Iannuzzi et al., 2001b, c, d).

In the present study we describe a new case of rcp in a normal-looking young bull of the Italian Chianina breed by using both banding and FISH mapping techniques. In addition, hormone analyses and histological evaluations of the testes, seminiferous tubules and the epididymis duct were performed.

\section{Materials and methods}

\section{Case description}

The young male was selected at the age of four months to be used for reproductive activity due to its good shape, body conformation and weight. When cytogenetic analyses revealed an abnormal karyotype, the male was designated for meat production only. From the age of 15 months, every 14 days and at seven subsequent times, peripheral blood samples were taken at the same hour $(7.00 \mathrm{a} . \mathrm{m}$.$) and serum levels of$ testosterone, $17 \beta$-estradiol and progesterone were detected by radioimmunoassay (Biodata kit, Serono). Similar analyses were conducted on four karyologically normal males of the same age and on two castrated males of the same herd. During this time, the carrier never showed libido in the presence of both males and females in oestrus. The male carrier was slaughtered at 18 months and 7 days, weighing $772 \mathrm{~kg}$. Then the testes, the epididymis, vas deferens and bulbo-urethral glands were excised. Both testes were photographed, measured and histologically examined. Sections were made from formalin-fixed tissues, mounted in paraffin, sectioned by microtome (5- $\mu \mathrm{m}$ sections) and stained with hematoxylin-eosin.

Cell cultures and cytogenetic analyses

Peripheral blood lymphocyte cultures, CBA- and RBA-banding, sequential RBA-banding/Ag-NOR technique and FISH-mapping were as reported earlier (Di Meo et al., 1993; Iannuzzi, 2003; Iannuzzi et al.,
2003). As probes, both caprine and bovine BAC-clones containing $I L 1 B, A S S$ and $L G B$ mapping to BTA11, as well as SERPINA and D21S45 mapping to BTA21 (Schibler et al., 1998; Eggen et al., 2001) were used. Chromosome identification, chromosome banding and gene locations followed ISCNDB 2000 (2001).

\section{Results and discussion}

\section{Hormonal and histological analyses}

No significant differences were detected in the levels of testosterone in both the male carrier $(6.31 \pm 1.127 \mathrm{ng} / \mathrm{l})$ and normal males $(6.67 \pm 1.192 \mathrm{ng} / \mathrm{l})$, while testosterone was not detectable in the two castrated males. Both $17 \beta$-estradiol and progesterone were not detectable in all studied animals, as expected. Both male carrier testes weights ( 314.8 and $313.2 \mathrm{~g}$ for the right and left, respectively) and their sizes $(16.6 \times 6.8$ and $16.4 \times 6.8 \mathrm{~cm}$, right and left, respectively) were in agreement with those of normal males of the same breed. Histological evaluation revealed a well-organized testis (Fig. 1) with seminiferous tubules divided by septal fibrovascular stroma and Leydig cells (Fig. 1A). Seminiferous tubules appeared normally developed and were lined by a germinal epithelium with Sertoli cells and a poor proliferative population of germ cells (Fig. 1B). The same situation was observed in the epididymis (Fig. 1C). In conclusion, germinal elements in all three examined sections mainly consisted of spermatogonia, middle pachytene spermatocytes and early spermatids while late spermatids and spermatozoa were very rare. Spermatozoa were rare also in ductal lumen of epididymis suggesting that $\mathrm{rcp}(11 ; 21)$ could affect fertility due to the formation of unbalanced gametes derived from erroneous divisions of quadrivalents at meiosis (Switonski and Stranzinger, 1998).

\section{Cytogenetic analyses}

All 100 normal stained metaphase plates of the young bull showed the presence of two abnormal chromosomes which were clearly longer or smaller than the largest (BTA1) and smallest (BTA29) chromosomes (Fig. 2A). These two derivative chromosomes were C-band positive (Fig. 2B) and 

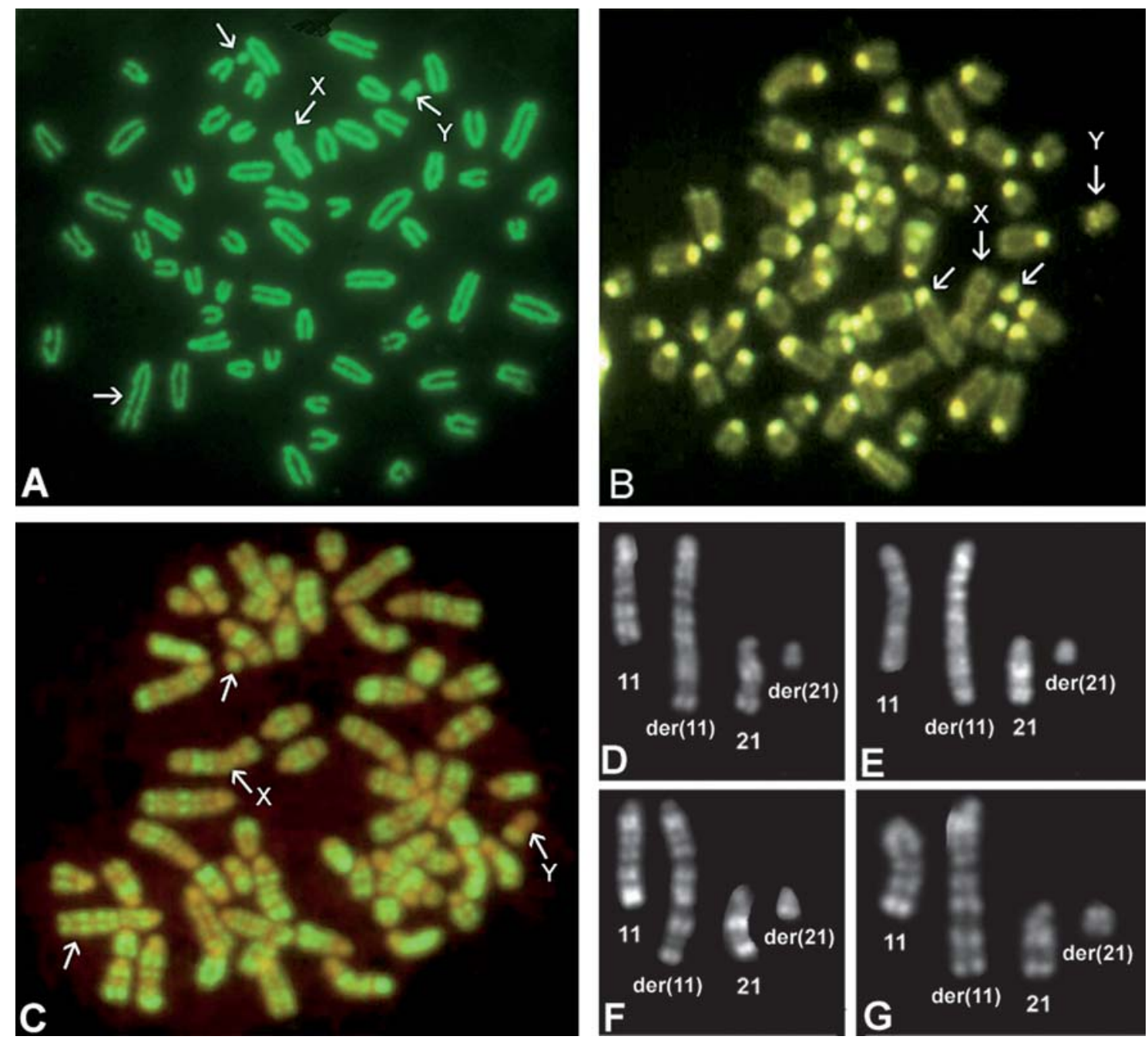

Fig. 2. Conventionally stained (A) and CBA-banded (B) metaphase plates of a young bull carrying the reciprocal translocation between BTA11 and BTA21, as revealed by RBA-banding (C-G). Sex chromosomes are indicated and both der(11) and der(21) were C-band positive (B).

thus their centromeres were conserved. The application of RBA-banding revealed that these two abnormal chromosomes were the product of a reciprocal translocation between BTA11 and BTA21 (Fig. 2C), as confirmed by FISH with specific molecular markers mapping to BTA11 (IL1B, ASS and LGB) and BTA21 (SERPINA and D21S45) (Fig. 3). Since BTA11 is a NOR-bearing chromosome and the NORs are located at the telomeres (Di Berardino et al., 1985), the sequential RBA-banding/Ag-NOR technique revealed that NORs were translocated from normal BTA11 to der(21) (Fig. 3F, G), further confirming rcp(11;21), as schematised in R-banded ideograms of both normal BTA11 and BTA21 and both der(11) and der(21) (Fig. 3H). The breaks occurred in the middle of positive R-band BTA11q28, between ASS (mapping on BTA11q28prox) and LGB (mapping on BTA11q28dist), as well as in the pericentromeric region of BTA21 (q12). Essentially, the large der(11) contains almost all of the two chromosomes, while the small der(21) appears as a mini-chromosome containing the centromere of BTA21 and part of the telomere of BTA11 (Fig. 3H).

The rare cases of rcp found in cattle are very probably due to the lack of routine analysis using banding techniques. Indeed, most labs apply only normal staining procedures to check for the presence of centric fusions. On the contrary, all examined animals, especially bulls used for reproduction or/and progeny test and females with reproductive disorders, should be karyotyped by using banding techniques at 450-band level (at least). Specialised, simple software is available today, making the interactive construction of a banded karyotype possible in only $30 \mathrm{~min}$. Only by using routine banding techniques, structural aberrations other than centric fusions, such as rcp and paracentric inversions, can be discovered and better characterized by using specific molecular makers (or chromosome paint- 

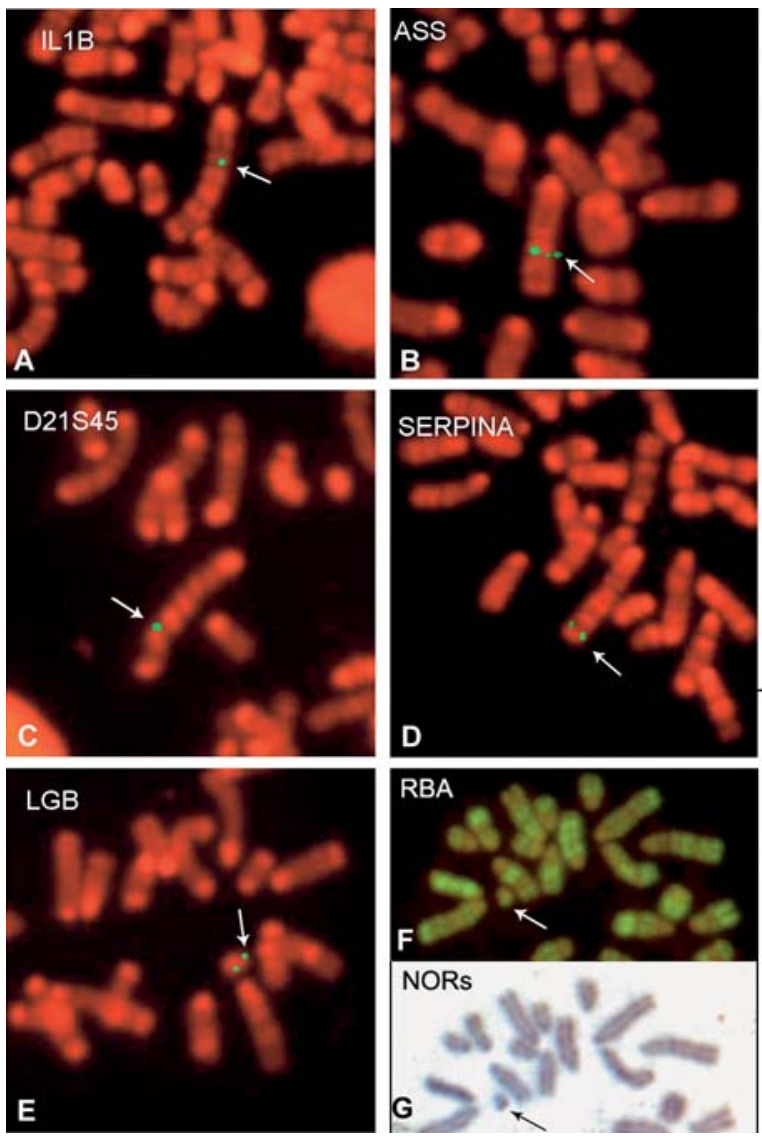
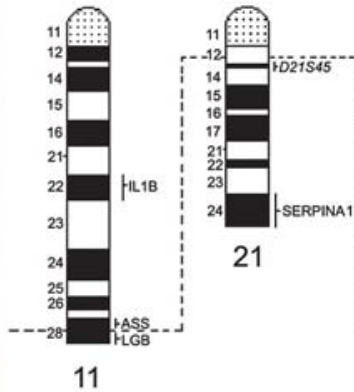

21

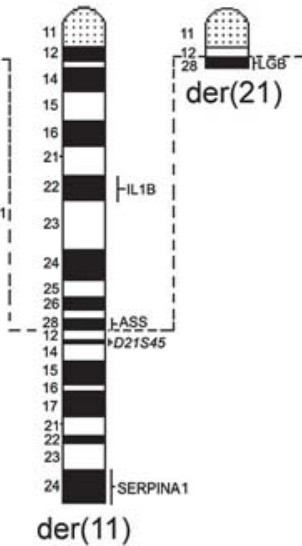

H

Fig. 3. FISH-mapping on cattle chromosomes carrying $\operatorname{rcp}(11 ; 21)$ by using specific markers of BTA11 (IL1B, ASS and $L G B)$ (A, B, E, respectively) and BTA21 (SERPINA1 and D21S45) (C, D, respectively). The last details $(\mathbf{F}, \mathbf{G})$ show the sequential RBA-banding $(\mathbf{F})$ and Ag-NORs (G) technique with the presence of NORs at the telomeres of $\operatorname{der}(21)$ (arrows). (H) R-banded ideograms of normal BTA11 and BTA21, as well as of der(11) and $\operatorname{der}(21)$ with the cytogenetic map of markers used. The dotted line indicates the exact points of break-joining between the two chromosomes originating $\operatorname{rcp}(11$; 21)(q28;q12). ing probes) at metaphase (Iannuzzi et al., 2001a, b, c, d) or interphase sperm (Pinton et al., 2004; Bonnet-Garnier et al., 2006), although no commercial probes, especially painting probes, are currently available for domestic animals. Furthermore, since the labs working on cattle focus primarily on centric fusion translocations which are more common in meat breeds than in milk breeds, several cattle milk breeding associations do not require a karyotype for bulls, with the result that several aberrations (i.e. rcp and inv) may spread in the progeny, especially when using artificial insemination.

\section{Acknowledgement}

The authors wish to thank Mr. A. Navarro, CNR-ISPAAM, Naples, Italy, for his invaluable technical assistance.

\section{References}

Ansari HA, Jung HR, Hediger R, Fries R, Konig H, Di Meo GP, Iannuzzi L, Perucatti A, Ferrara L: Stranzinger G: A balanced autosomal reciprocal translocation in an azoospermic bull. Cytogenet Cell Genet 62:117-123 (1993).

Bonnet-Garnier A, Pinton A, Berland HM, Khireddine B, Eggen A, et al: Sperm nuclei analysis of $1 / 29$ Robertsonian translocation carrier bulls using fluorescence in situ hybridisation. Cytogenet Genome Res 112:241-247 (2006).

de Schepper GG, Aalbers JG, Te Brake JHA: Double reciprocal translocation heterozygosity in a bull. Vet Rec 110:197-199 (1982).

Di Berardino D, Lioi MB, Iannuzzi L: Identification of nucleolus organizer chromosomes in Cattle (Bos taurus L.) by sequential silver staining + RBA banding. Caryologia 38:95-102 (1985). Identification of nucleolus organizer chromosomes in sheep (Ovis aries L.) by sequential GBG/Ag-NOR and RBG/Ag-NOR techniques. Cytobios 75:183-190 (1993).

Ducos A, Dumont P, Séguéla A, Pinton A, Berland $\mathrm{H}$, et al: A new reciprocal translocation in a subfertile bull. Genet Sel Evol 32:589-598 (2000).

Dyrendahl I, Gustavsson I: Sexual functions, semen characteristics and fertility of bulls carrying 1; 29 chromosome translocation. Hereditas 90: 281-289 (1979).

Eggen A, Gautier M, Billaut A, Petit E, Hayes H, et al: Construction and characterization of a bovine BAC library with four genome-equivalent coverage. Genet Sel Evol 33:543-548 (2001).

Gustavsson I: Cytogenetics, distribution and phenotypic effects of a translocation in Swedish cattle. Hereditas 63:68-169 (1969).
Gustavsson I: Chromosome aberrations and their influence on the reproductive performance of domestic animals - a review. Z Tierzuchtg Zuchtgsbiol 97:176-195 (1980).

Iannuzzi L: Methodologies applied to domestic animal chromosomes. Methods Mol Biol 240:1534 (2003).

- Iannuzzi L, Di Meo GP, Perucatti A, Incarnato D, Schibler L, Cribiu EP: Comparative FISH-mapping of bovid X chromosomes reveals homologies and divergences between the subfamilies Bovinae and Caprinae. Cytogenet Cell Genet 89:171-176 (2000).

Iannuzzi L, Di Meo GP, Leifsson PS, Eggen A, Christensen K: A case of trisomy 28 in cattle revealed by both banding and FISH-mapping techniques. Hereditas 134:147-151 (2001a). 
Iannuzzi L, Di Meo GP, Perucatti A, Incarnato D, Molteni L, et al: A new balanced autosomal reciprocal translocation in cattle revealed by banding techniques and HSA-painting probes. Cytogenet Cell Genet 94:225-228 (2001b).

Iannuzzi L, Molteni L, Di Meo GP, De Giovanni A, Perucatti A, et al: A case of azoospermia in a cattle bull carrying a Y-autosome reciprocal translocation. Cytogenet Cell Genet 95:225227 (2001c).

Iannuzzi L, Di Meo GP, Perucatti A, Eggen A, Incarnato D, et al: A pericentric inversion in cattle Y-chromosome. Cytogenet Cell Genet 94:202205 (2001d)

Iannuzzi L, Perucatti A, Di Meo GP, Schibler L, Incarnato D, Cribiu EP: Chromosomal localization of sixty autosomal loci in sheep (Ovis aries, $2 \mathrm{n}=54$ ) by fluorescence in situ hybridization and R-banding. Cytogenet Genome Res 103: 135-138 (2003).
ISCNDB 2000: International System for Chromosome Nomenclature of Domestic Bovids. Di Berardino D, Di Meo GP, Gallagher DS, Hayes $\mathrm{H}$, Iannuzzi L (co-ordinator) (eds). Cytogenet Cell Genet 92:283-299 (2001).

Kovács A, Villagomez DAF, Gustavsson I, Lindblad $\mathrm{K}$, Foote RH, Howard TH: Synaptonemal complex analysis of a three-breakpoint translocation in a subfertile bull. Cytogenet Cell Genet 61:195-201 (1992).

Long SE: Cytogenetics, in Meredith MJ (ed): Animal Breeding and Infertility, p 39-61 (Blackwell Science Ldt, Victoria 1995).

Mayr B, Krutzler H, Auer H, Schleger W: Reciprocal translocation 60,XY,t(;15) $(21 ; 24)$ in cattle. J Reprod Fertil 69:629-630 (1983).

Molteni L, De Giovanni Macchi A, Canotti M: Effetti della traslocazione $t$; 29 sulla efficienza riproduttiva nelle bovine Marchigiane. Taurus VIII:23-25 (1994).

Pinton A, Ducos A, Yerle M: Estimation of the proportion of genetically unbalanced spermatozoa in the semen of boars carrying chromosomal rearrangements using FISH on sperm nuclei. Genet Sel Evol 36:123-137 (2004).
Popescu CP, Pech A: Une bibliographie sur la translocation $1 / 29$ de bovins dans le monde (19641990). Ann Zootecn 40:271-305 (1991).

Rangel-Figueiredo T, Iannuzzi L: Frequency and distribution of rob $(1 ; 29)$ in three Portuguese cattle breeds. Hereditas 119:233-237 (1993).

Schibler L, Vaiman D, Oustry A, Giraud-Delville C, Cribiu EP: Comparative gene mapping: a finescale survey of chromosome rearrangements between ruminants and humans. Genome Res 8:901-915 (1998).

Switonsky M, Stranzinger G: Studies of synaptonemal complexes in farm mammals: a review. J Hered 89:473-480 (1998).

Villagomez DAF, Anderson M, Gustavsson I, Ploen $\mathrm{L}$ : Synaptonemal complex analysis of a reciprocal translocation, rcp $(20 ; 24)(\mathrm{q} 17 ; \mathrm{q} 25)$, in a subfertile bull. Cytogenet Cell Genet 62:124130 (1993). 